\title{
1980年代初頭に建設された既存鉄骨建物の溶接品質と現有耐震性能 WELDING QUALITY AND SEISMIC PERFORMANCE OF EXISTING STEEL BUILDINGS CONSTRUCTED IN EARLY 1980S
}

\author{
吹田 啓一郎*, 佐 藤 有 希**, 長田暢 浩*** \\ Keïchiro SUITA, Yuki SATOH and Nobuhiro NAGATA
}

\begin{abstract}
This paper presents results of welding inspection and loading tests conducted to beam-to-column connections cut out from two existing steel buildings constructed in the early 1980s. From the results of thorough welding inspections, i.e. macrostructure tests and ultrasonic inspection, characteristics of welding defects are investigated regarding the location of defects in the deposited metals, kind of defects, and the rate of occurrence. From the results of dynamic loading tests conducted on the beam-to-column connections, the influence of defects on the deformation capacity and the failure procedure are observed.
\end{abstract}

\author{
Keywords : existing building, beam-to-column connection, welding defect, ultrasonic inspection, \\ dynamic loading test, deformation capacity, \\ 既存建物, 柱梁接合部, 溶接欠陥, 超音波探傷検査, 動的載荷実験, 変形能力
}

\section{1.はじめに}

建築物の地震被害に関する予測や防災対策を考えるには実在する建 物の耐震性能を精度よく評価することが求められる.鉄骨構造では兵 庫県南部地震の被害とその後の研究から, 溶接接合部の設計・施工の 違いにより早期に破断することがあり, その解決には施工技量, 接合 詳細や品質管理技術も重要であることが分かってきた. 鉄骨構造の普 及は圧延H形鋼の製造により1960年代から本格化し，1970年代から 柱に角形鋼管を用いるラーメン構造が増え始め, 1981 年の新耐震設 計法からは大半がこの形式を採用し,いずれも柱梁の接合は溶接が主 流となり現在に至っている. このような変遷が明らかであっても, 溶 接の品質と性能を知らずにその時々の設計規範や構造形式, 工法など の条件だけから建物が現有する耐震性能を予測することは難しい.

溶接接合部に欠陥がある場合の力学性能は, 加藤ら1〜3)による人 工欠陥のある平板の突合せ溶接部の引張実験, 藤本ら 4,5 によよる未溶 着のある $\mathrm{T}$ 継手の疲労実験, 佐藤ら 6,7)による切欠きのある $\mathrm{T}$ 継手の 引張実験, 小野ら8～10)による切欠付平板や人工未溶着を有する梁端 溶接部の実験, さらに兵庫県南部地震後の鈴木ら 11), 嶋ら 12), 田㴊 ら13)による人工欠陥を有する柱梁接合部の実験など、多くの研究が 行われて欠陥の幾何学的条件あるいは破壊靶性などの材料特性と破壊 との関係が明らかにされてきた. だが,これらの研究はいずれも人工
的な欠陥を対象にしており, 実際の施工で発生する溶接欠陥の実態 と,そのような欠陥を有する接合部の構造性能を明らかにした研究は 少ない14). 現在の材料と溶接技術で各時代の構造物を再現することは 容易ではなく, 施工品質の影響を受ける性能の実態を知るには実物を 相手に実測調查を重ねて情報を蓄積する以外に方法はない。

この研究は 1980 年代初頭に建設された鉄骨建物が解体されたもの を対象に, その現有性能を実験的に調べたものである.溶接柱梁接合 部を対象にまず材料試験や超音波探傷検査（UT検査）で予め機械的 性質と溶接欠陥を調べ, 次いで切り出した架構の一部を破壊に至るま で載荷して履歴特性と破壊過程を明らかにし, その後, 溶接部を切り 出して破断状況を観察した.このような手順で当時の鋼材特性と溶接 施工技術を確認し, 欠陥を有する接合部が保有する変形能力について 定量的な情報を得た

また, 施工品質に応じて耐震対策を検討するには, 既存鉄骨建物の 欠陥を検出する技術が重要となる. 溶接の普及に伴って品質を確認す るための検査法も発展し, 中でも超音波探傷検査（UT 検査）は加藤 ら 1,2$)$ の研究で有効な検査法が確立されて以来, 鉄骨建物に適した方 法として検査規準15)が整備され，現在も広く活用されている.だが, 機器やディテールが今と異なる旧世代の溶接技術と技量で実際に発生 する様々な欠陥に対して, 今のUT検查がどれほどの検出能力を持つ

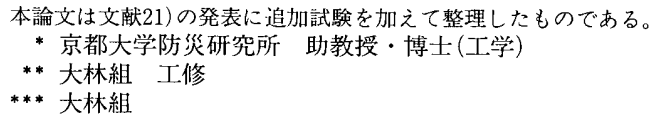

本論文は文献21)の発表に追加試験を加えて整理したものである。

*** 大林組

Assoc. Prof., Disaster Prevention Research Institute, Kyoto University, Dr. Eng. Obayashi Corp., M. Eng.

Obayashi Corp. 
かについては, 十分な検証がされていない,そこで載荷実験後の試験 体溶接部を切断してマクロ試験により実際の欠陥位置と種類を確認 し，事前のUT検査結果と照合することにより検出精度を調べ，また 欠陷発生状況の詳細を確認した.これらの実験や検査を通して,一例 ではあるが1980年初頭の鉄骨建物の柱梁接合部の溶接品質と現有す る力学性能を調べた。

\section{2. 対象建物}

\section{1 建物の概要と鋼材}

調査対象は 1980 年建設の建物 A, 1981 年建設の建物 B の 2 棟あ り、いずれも平屋建で平面，立面を図 1 に示す，建物 $\mathrm{A}$ は $1 \times 4$ スパ ン，建物 B は $1 \times 2$ スパンで、いずれも X 方向両側に長い片持梁が 張り出している．構造形式は純ラーメン構造で角形鋼管柱と $\mathrm{H}$ 形鋼 梁を通しダイアフラム形式で溶接接合している.この構成は現在, 最 も広く用いられているものであり,これが普及する初期の建設とみる ことができる．2棟の用途や設計仕様はほぼ同じだが，施工者は異な る. 図中の波線で囲った 7 箇所の柱梁接合部を特に重点的に調査し た、図中の記号は後述の載荷実験の名称を示し、先頭の L は梁が片 側だけの L 形，Tは両側に梁のある T 形の試験体を意味する.

梁はSS400 材の H-350 × $175 \times 7 \times 11$ ，柱はSTKR400の $\square-250$ $\times 250 \times 9$ で，断面の幅厚比は柱，梁ともにFAランクである．Y力

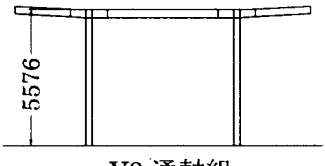

Y3 通軸組

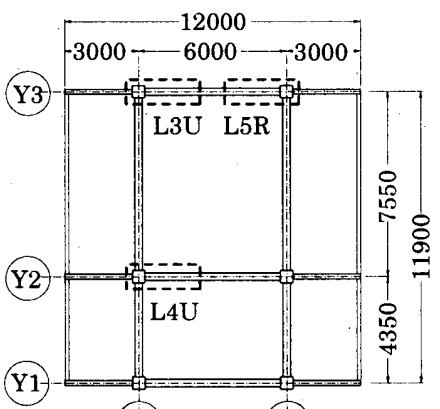

(X1)<smiles>[Y]C[Y]</smiles>

(unit:mm)

(a) 建物 A

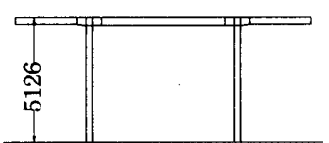

Y1 通軸組

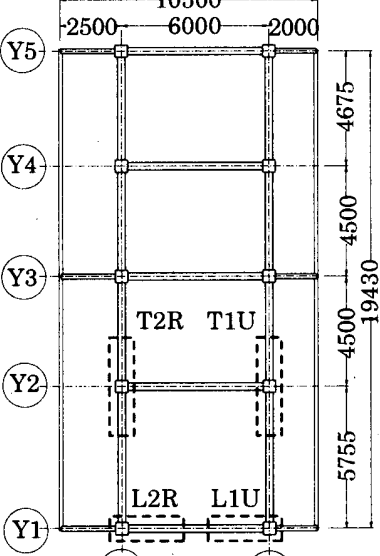

(X1)

(x) (b) 建物 B

向通りの梁と, X方向通りの片持梁は梁端に溶接組立のハンチを設け て断面を H-300 × $150 \times 6.5 \times 9$ としている．通しダイアフラムは板 厚 $12 \mathrm{~mm}$ である．引張試験による柱，梁の機械的性質を表 1 に、シャ ルピー衝撃試験による梁フランジの遷移曲線を図 2 に示す，遷移温度 は吸収エネルギーで $11.5^{\circ} \mathrm{C}$ 、脆性破面率で $2.1^{\circ} \mathrm{C}$ であり、. $0^{\circ} \mathrm{C}$ での吸収 エネルギーは $79.5 \mathrm{~J}$ である。これらの鋼材の特性は現在の SN 材や BCR 材の規格も満足している.

\section{2 柱梁接合部}

柱梁接合部の詳細をL 形について図 3 に示す．上ダイアフラムは屋 根面のブレース端接合部のガセットプレートを兼用しているので形状 は不整形で柱フェイスからの出寸法が $125 \mathrm{~mm}$ と大きい. 下ダイアフ ラムは $20 \mathrm{~mm}$ の出寸法である.なお, T形は両側に梁ハンチがある以 外は L 形と同じである．図中に M1〜M4で示す太線は後述のマクロ 試験片の採取位置を示す。

図4に採用された溶接の種類を示す．現在の柱梁接合部に用いられ る方法と同じであり，以下ではバネルとダイアフラムの溶接を $\mathrm{SU}$, $\mathrm{SL}$, 梁フランジとダイアフラムの溶接を FU, FL, 柱とダイアフラム の溶接を CL と呼ぶ．梁フランジの完全溶込み溶接（FU, FL）はス カラップ工法が採用されているが、現在の標準的な溶接詳細と比較す ると以下の点が異なっている。

(1) スカラップ: 加工はガス切断により, 半径は $28 \sim 42 \mathrm{~mm}$ の間で一 定ではない. スカラップ底にはアールを設けず, フランジの内面に対 してほぼ垂直に切断されている. また, 開先加工も同様にガスで切断 した後にグラインダで仕上げたものと推察される.

(2) 裏当て金とエンドタブ:ガウジングによる裏はつり形式を採用し 裹当て金は使っていない. 裹はつりの作業性のために梁フランジの開

\section{表 1 鋼材の引張試験結果（JIS Z2201 1 号試験片）}

\begin{tabular}{|c|c|c|c|c|c|c|c|c|}
\hline 建物 & 断面 & 部位 & $\begin{array}{l}\text { 上降伏点 } \\
\mathrm{N} / \mathrm{mm}^{2}\end{array}$ & $\begin{array}{l}\text { 下降伏点 } \\
\mathrm{N} / \mathrm{mm}^{2}\end{array}$ & $\begin{array}{l}\text { 引張強さ } \\
\mathrm{N} / \mathrm{mm}^{2} \\
\end{array}$ & $\begin{array}{c}\text { 破断 } \\
\text { 伸び } \\
\% \\
\end{array}$ & $\begin{array}{c}\text { 絞り } \\
\%\end{array}$ & $\begin{array}{c}\text { 降伏比 } \\
\% \\
\end{array}$ \\
\hline \multirow{3}{*}{ A } & $-250 \times 250 \times 9$ & 柱管壁 & \multicolumn{2}{|c|}{$352 *$} & 451 & 23.5 & 42.6 & 77.9 \\
\hline & \multirow[b]{2}{*}{ H- $350 \times 175 \times 7 \times 11$} & フランジ & 330 & 320 & 467 & 26.2 & 41.4 & 70.7 \\
\hline & & ウェブ & 367 & 353 & 481 & 25.8 & 54.6 & 76.3 \\
\hline \multirow{5}{*}{ B } & $\square .250 \times 250 \times 9$ & 柱管壁 & \multicolumn{2}{|c|}{$348 *$} & 444 & 22.3 & 34.5 & 78.3 \\
\hline & \multirow[b]{2}{*}{$\mathrm{H}-350 \times 175 \times 7 \times 11$} & フランジ & 341 & 321 & 463 & 28.3 & 40.1 & 73.7 \\
\hline & & ウェプ & 380 & 361 & 479 & 26.3 & 46.4 & 79.2 \\
\hline & \multirow{2}{*}{$\mathrm{H}-300 \times 150 \times 6.5 \times 9$} & フランジ & 314 & 311 & 436 & - & 41.9 & 72.1 \\
\hline & & ウェブ & 354 & 335 & 442 & 27.0 & 43.8 & 80.2 \\
\hline
\end{tabular}

$* 0.2 \%$ offset

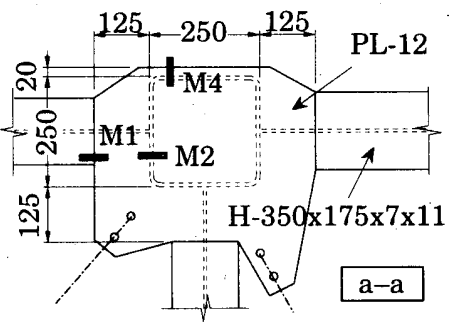

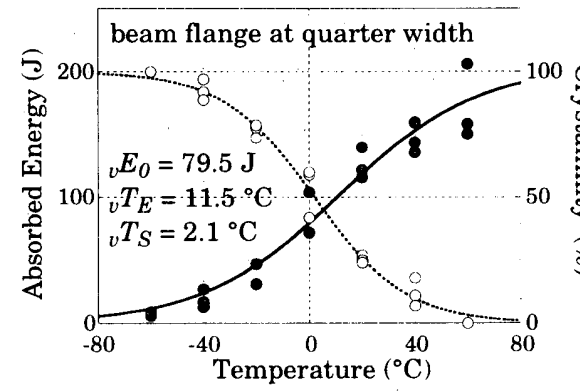

図 2 シャルピー衝撃試験結果 (JIS Z2201 V ノッチ試験片)

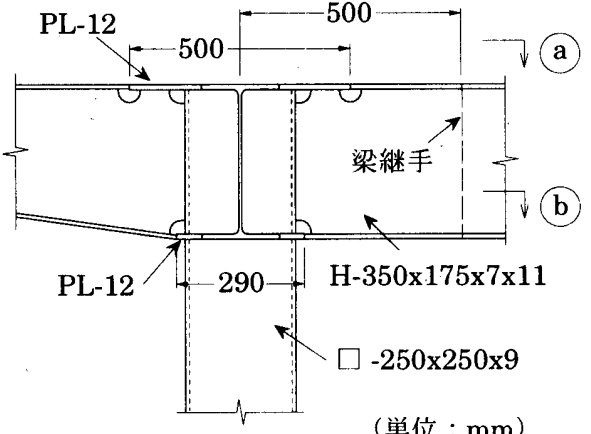

(単位 $: \mathrm{mm}$ )

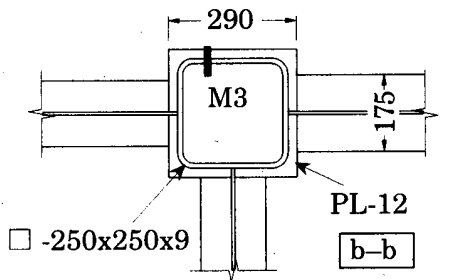

図 3 柱梁接合部詳細（図中の M1〜 M4 はマク口試験片採取位置） 
先はすべて内開先である，開先と裏はつりはマクロ試験で確認でき， 写真とそのスケッチを図5に示す. 図中の(1)(2)(3)の順に溶接を積層し た後、(1)のルート部をガウジングではつり，最後に(4)を裏溶接したと 推察される.柱とダイアフラムの完全溶込み溶接には裹当て金を使用 しているが，母材との密着が十分でない場合が多く，図6に例を示す ように大きいところで $3 \mathrm{~mm}$ ほどの隙間が確認された。

\section{3. 溶接部の検査結果 \\ 3.1 超音波探傷検査}

図 1 に示した 7 箇所の柱梁接合部を対象にUT3 種(日本非破壊検査 協会)、の資格者によりUT検査を行った，文献 15)の判定基準に従い. 接合部別に集計した合格数などを表 2 に示す. 全体で 126 の検査筒所 があり，その中から 212 個の欠陥が検出された。合格と判定された溶 接は 40 笝所で合格率は $31.7 \%$ とかなり低い，建物別に見ると 2 棟の 間での違いが顕著である，建物 $\mathrm{A}$ は全検査数が 52 箇所であり、1箇 所あたり平均 2.6 個の欠陥が見つかって合格率は $11.5 \%$ と低いのに対 し，建物 B は全検査数が 74 箇所で 1 箇所につき平均 1.1 個の欠陥が 見つかり，合格率は $45.9 \%$ である，2棟の建物の間では 1 本の溶接線 （1検査籄所）に含まれる欠陥数で 2.5 倍, 合格率で 4 倍ほどの差があ る. これは溶接技能者の技量. 使用する設備や溶接条件, 品質管理技 術などによる差が現れたものと推察される.

次に, 溶接部位別に集計した判定結果を表 3 に示す. 2 棟全体の合 格率は，柱とダイアフラムの溶接(CL)が $5 / 28=17.9 \%$ ，パネルとダイ
アフラムの溶接が下部(SL)は $5 / 28=17.9 \%$ ，上部(SU)は 4/28=14.3\% となり、全溶接部の平均合格率 $31.7 \%$ よりも低い. 建物別に見てもこ の 3 籄所が平均より低い傾向は共通している。一方, 梁フランジ溶接 は下フランジ(FL)が 12/21=57.1\%，上フランジ(FU)が 14/21=66.7\% で，全平均合格率 $31.7 \%$ よりも高い。特に建物 Bの FU, FLは 70 $90 \%$ の合格率で，これは全平均合格率より 2 倍以上高くなっている. このように、同じ建物の中でも溶接位置により合格率には顕著な差が 見られた。ここで梁フランジに欠陥が少ない理由の一つに，衣はつり によって初層の欠陥が除去されたことが考えられる.

さらに、溶接継目の断面における欠陥位置の分布を調べた．特に欠 陥が多く見られた CL，SL，SUを対象に，溶接継目の断面を板厚方 向. 幅方向にそれぞれ 3 分割して図 7 に示す 9 領域に分け, 各領域の 欠陥数を集計して表 4 に示す. 板厚方向に 3 等分した初層, 中層, 表 層に分けて比較すると, 合計 212 個の欠陥の $82.5 \%$ に当たる 175 個が 初層に位置している. 特に初層のダイアフラム側では 87 個の欠陥が 検出され，この領域だけで全体の $41.0 \%$ を占めている．また，継目内 の幅方向に比較すると, ダイアフラム側, 中間, 開先側はそれぞれ $47.2 \%, 21.2 \% 、 31.6 \%$ であり, 中間よりも, 両側の母材と融合する 位置に欠宿が多い，などの特徵が見られた。

\section{2 マクロ試験}

UT検査で欠陥が検出された位置を対象に。重点的にマクロ試験を 行った. 後述の載荷実験後に塑性変形の生じていない位置から試験体

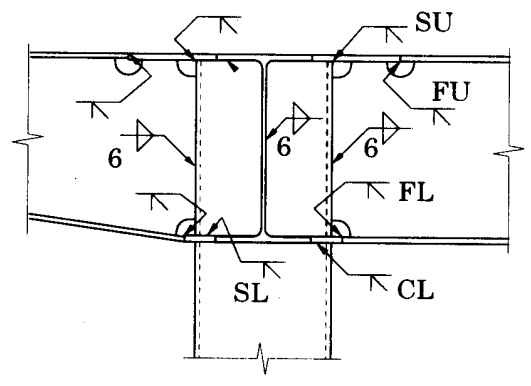

図 4 柱梁接合部の溶接種類と位置記号

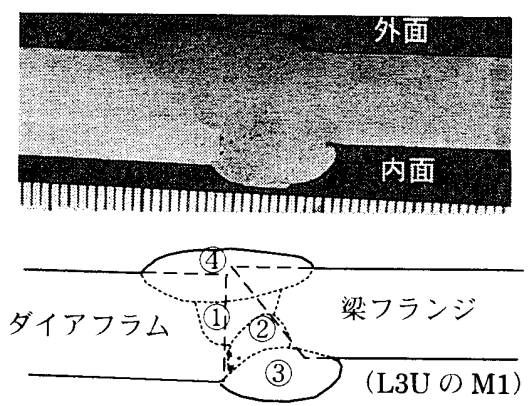

(L3U の M1)

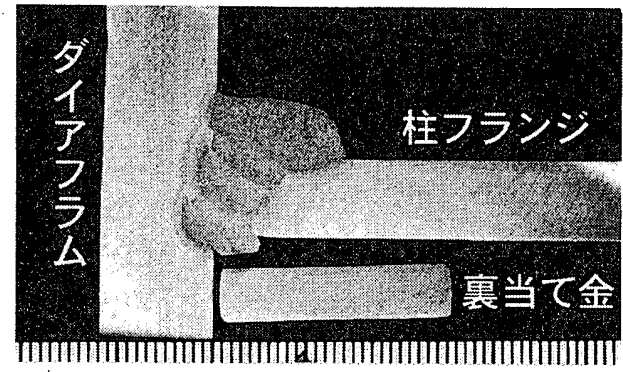

(L3U の M2)

表 2 UT 検査による判定結果の全体集計

\begin{tabular}{|c|c|c|c|c|c|c|}
\hline 建物 & 接合部位置 & 検査数 & 合格数 & 合格率(\%) & 欠陥数 & 1䈯所当り欠陥数 \\
\hline \multirow{4}{*}{$\mathrm{A}$} & X1Y3(L3U) & 18 & 0 & 0.0 & 64 & 3.56 \\
\hline & $\mathrm{X} 1 \mathrm{Y} 2(\mathrm{~L} 4 \mathrm{U})$ & 16 & 1 & 6.3 & 31 & 1.94 \\
\hline & X2Y3(L5R) & 18 & 5 & 27.8 & 39 & 2.17 \\
\hline & 合計 & 52 & 6 & 11.5 & 134 & 2.58 \\
\hline \multirow{5}{*}{ B } & $\mathrm{X} 1 \mathrm{Y} 1(\mathrm{~L} 2 \mathrm{R})$ & 18 & 9 & 50.0 & 15 & 0.83 \\
\hline & $\mathrm{X} 1 \mathrm{Y} 2(\mathrm{~T} 2 \mathrm{R})$ & 18 & 5 & 27.8 & 25 & 1.39 \\
\hline & $\mathrm{X} 2 \mathrm{Y} 1(\mathrm{~L} 1 \mathrm{U})$ & 18 & 14 & 77.8 & 9 & 0.50 \\
\hline & $\mathrm{X} 2 \mathrm{Y} 2(\mathrm{~T} 1 \mathrm{U})$ & 20 & 6 & 30.0 & 29 & 1.45 \\
\hline & 合計 & 74 & 34 & 45.9 & 78 & 1.05 \\
\hline \multicolumn{2}{|r|}{ 合計 } & 126 & 40 & 31.7 & 212 & 1.68 \\
\hline
\end{tabular}

表 3 溶接位置別の UT 検査判定結果

\begin{tabular}{|c|c|c|c|c|c|c|}
\hline 建物 & \multicolumn{3}{|c|}{$\mathrm{A}$} & \multicolumn{3}{c|}{$\mathrm{B}$} \\
\hline 位置 & 検査数 & 合格数 & $\begin{array}{c}\text { 合格率 } \\
(\%)\end{array}$ & 検査数 & 合格数 & $\begin{array}{c}\text { 合格率 } \\
(\%)\end{array}$ \\
\hline CL & 12 & 0 & 0.0 & 16 & 5 & 31.3 \\
\hline SL & 12 & 0 & 0.0 & 16 & 5 & 31.3 \\
\hline SU & 12 & 1 & 8.3 & 16 & 3 & 18.8 \\
\hline FL & 8 & 3 & 37.5 & 13 & 9 & 69.2 \\
\hline FU & 8 & 2 & 25.0 & 13 & 12 & 92.3 \\
\hline 合計 & 52 & 6 & 11.5 & 74 & 34 & 45.9 \\
\hline
\end{tabular}

表 4 溶接継目内の位置別のUT 検査判定結果

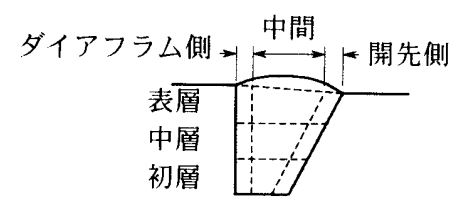

図 7 溶接継目の領域分割

\begin{tabular}{|c|c|c|c|c|c|c|c|c|c|r|}
\hline \multirow{2}{*}{ 位置 } & \multicolumn{3}{|c|}{ タイアフラム側 } & \multicolumn{3}{c|}{ 中間 } & \multicolumn{3}{|c|}{ 開先側 } & \multirow{2}{*}{ 合計 } \\
\cline { 2 - 12 } & 初層 & 中層 & 責 & 初層 & 中層 & 表層 & 初層 & 中層 & 表層 & \\
\hline $\mathrm{CL}$ & 27 & 0 & 4 & 4 & 4 & 2 & 25 & 2 & 3 & 71 \\
\hline $\mathrm{SL}$ & 24 & 2 & 1 & 11 & 1 & 2 & 17 & 1 & 1 & 60 \\
\hline $\mathrm{SU}$ & 36 & 3 & 3 & 18 & 2 & 1 & 13 & 2 & 3 & 81 \\
\hline 合計 & 87 & 5 & 8 & 33 & 7 & 5 & 55 & 5 & 7 & 212 \\
\hline 比率 (\%) & 41.0 & 2.4 & 3.8 & 15.6 & 3.3 & 2.4 & 25.9 & 2.4 & 3.3 & 100 \\
\hline
\end{tabular}


の溶接部を切断して試験片を採取した。試験片は建物 A の X1Y3 （L3U）から 7 片. X1Y2（L4U）から 2 片, 建物 B の X2Y2（T1U） から 1 片の計 10 片である. 採取位置の一例を図 3 に 1 1 M 4 の記号 を付して太線で示す. 1片につき 2 断面ずつ, 計 20 断面に含まれる 33 の溶接継目を試験の対象とした。

マクロ試験により合計 46 の欠陥が確認された。准の種類別に見 るとスラグ巻込み 19 , 融合不良 6 , 割れ 10 , 溶込み不良 3, ブローホー ル 1，オーバーラップ 6、アンダーカット 1 である. マクロ試験の例 を図 8，9に示す．予め行ったUT 検査で確認された欠陥位置も同図 (c)に示す．図8 のSLのスラグ巻き込み，図 9 の割れはUT検査でも 対応する位置に欠陥が検出されているが, 図 8(b)右側のCLの割れの ようにUTで検出されなかった欠陥もある.

5 種類の欠陥について, 種類別の欠陥発生位置を図 10(a) (e)に示 す。また全ての欠陥の発生位置を重小て図 10 (f)に示す。ここでは。 オーバーラップとアンダーカットの外部欠陥, 裹当て金の組立溶接と 余盛で確認された欠陥はUT 検查範囲外なので除き, 残る 37 個の欠 陥位置を示した．図中のマーカーが欠陥の位置を示し，はマクロ試 験で確認された欠陥が UT検査でも検出された場合を示し，Oはマク ロで見つかった欠陥がUT検查で検出されなかった場合を示す．

UT検査とマクロ試験の結果を照合した結果, マクロ試験で確認さ れた欠陥 37 のうちUT検査で検出された欠陥は 28 である.ここで， マク口試験の欠陥数に対するUT検査の欠陥数の比をUT検出率と定 義すると, 全欠陥のUT検出率は 76\%である. 欠陥の種類別に発生位 置とUT検出率を調べると次の特徵が見られる，スラグ巻込みは板厚 方向の偏りがなく, UT検出率は $13 / 18=72 \%$ である. 融合不良はフラ ンジ開先側に多く見られ，板厚方向の偏りがなく，UT 検出率は $4 / 6$

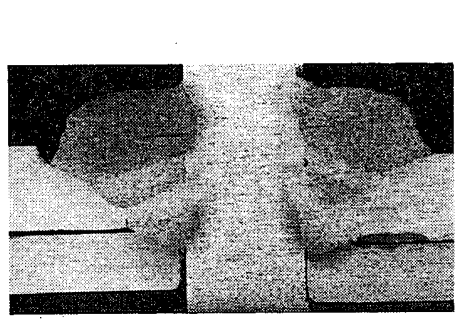

(a) マクロ試験

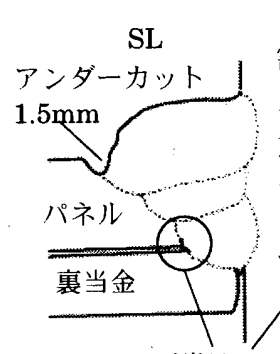

スラグ巻込み

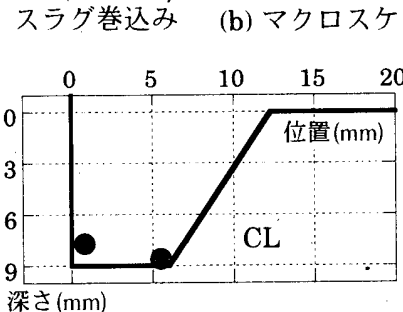

X1Y3（L3U）の M3 位㯰

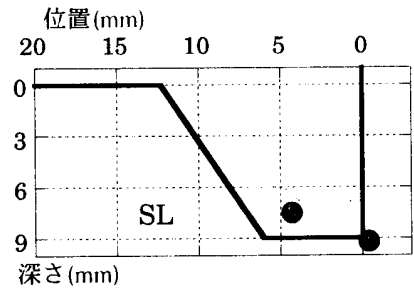

(c) UT 検査による欠陥

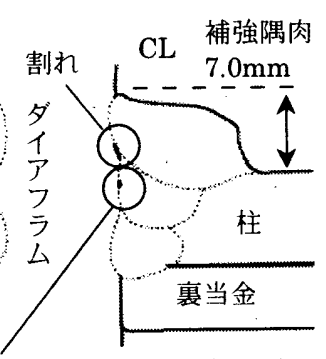

(b) マクロスケッチ

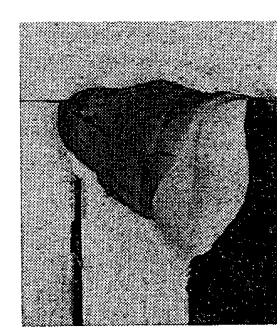

(a) マクロ試験

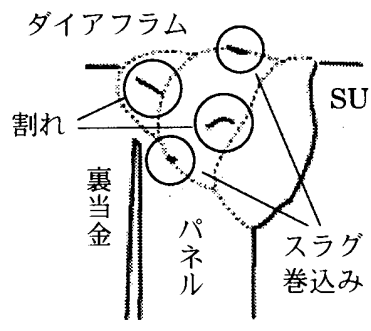

(b) マクロスケッチ

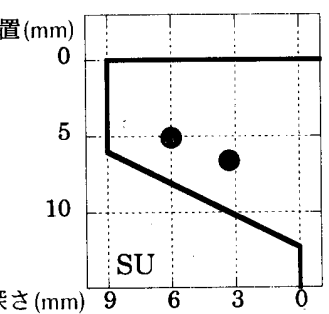

図 8 下ダイアフラムにおけるマクロ試験とUT 検査の例

(c) UT 検査による欠陥 $\mathrm{X} 1 \mathrm{Y} 3$ （L3U）の M4 位置
$=67 \%$ である. 割れは開先側の初層に多く，また幅方向の中間にも見 られる。UT検出率は $7 / 9=78 \%$ で高い，溶込み不良はダイアフラム側

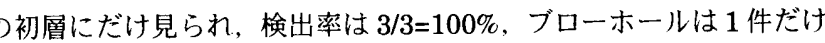
検出率は 100\%であった。

個数が少ない溶込み不良やブローホールを除くと, 欠陥の種類によ 多イアフラム側，中間，開先側の幅方向の位置の違いに 順に高い検出率となり、1.8倍ほどの差が見られた，表層の検出率が 低い理由の一つに, 対象が角形鋼管の柱, パネルとの溶接部であり, 初層は直接波で探査するが, 表層は反射波で探査するという, 探査条 件の違いが考えられる. 裹はつり形式の梁フランジの場合は両面から

\section{4. 柱梁接合部の載荷実験}

前章で説明した溶接欠陥を持つ柱梁接合部の塑性変形能力を, 部分 架構試験体による繰返し載荷実験で確認した。試験体は図 1 の記号末 表 5 マクロ試験との照合によるUT 検査の欠陥検出率

\begin{tabular}{|c|c|c|c|c|}
\hline 位置 & ダイアフラム側 & 中間 & 開先側 & 合計 \\
\hline 表層 & $3 / 6$ & $1 / 2$ & - & $4 / 8$ \\
\hline 中層 & $2 / 3$ & $1 / 1$ & $5 / 7$ & $8 / 11$ \\
\hline 初層 & $4 / 5$ & $2 / 2$ & $10 / 11$ & $16 / 18$ \\
\hline 合計 & $9 / 14$ & $4 / 5$ & $15 / 18$ & $28 / 37$ \\
\hline
\end{tabular}

図 9 上ダイアフラムにおけるマクロ試験とUT 検査の例

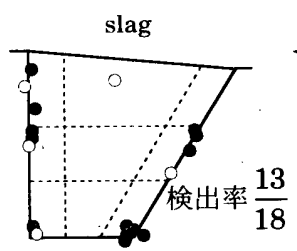

(a) スラグ巻込み

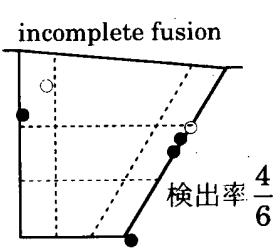

(b) 融合不良

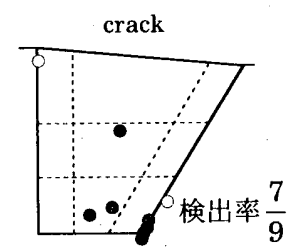

(c) 割れ

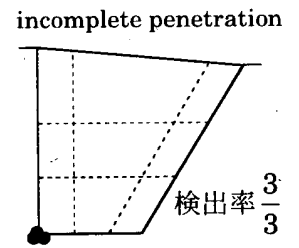

(d) 溶込み不良

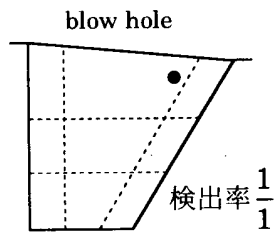

(e) ブローホール

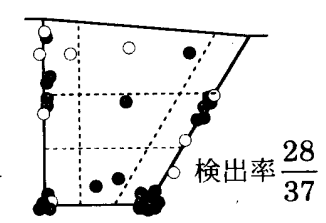

(f) 全欠陥

図 10 マク口試験による欠陥種類別の発生位置とUT 検查の検出率 
の 1 体である. 記号末尾に R を付した 3 体は文献 16)で補強策の性能 確認に用いたので、ここではふれない. L形は柱心から $500 \mathrm{~mm}$ 、 T形 は750mmの位置に高力ボルト摩擦接合の梁継手が設けられているが、 試験体では全て溶接により接合しなおした. 載荷実験の対象となる接 合部は、前述のUT検査で予め欠陥の位置を調べ、また外観検査によ る表 6 の結果を得た。外観の不具合は梁フランジに多く見られ，始終 端の溶込み不良や余盛の不足が見られる. 材料試験による強度から柱 と梁の全断面, および梁のスカラップ欠損を考慮した有効断面につい て全塑性モーメント ${ }_{c} M_{p},{ }_{b} M_{p},{ }_{b} M_{p e}$ を求め, 試験体の曲げモーメン トがこの全塑性モーメントに達するときの載荷荷重 ${ }_{c} P_{y},{ }_{b} P_{y},{ }_{b} P_{y e}$ を それぞれ求めて表 7 に示す.この值が最小となる断面で塑性化が先行 すると考えられ，L形は梁端のスカラップ欠損のある断面，T形は柱 の端部がこれに該当する計算となる。

\section{2 実験方法}

図 11 に 2 種類の試験体と載荷装置の全体を示す. L形は柱梁接合部 の片持ばり側から載荷し、反対側の梁端はリンク材でローラー支持し た．また T形では，梁両端をピン支持し，柱の先端から載荷した，い ずれも図中に示す試験体の各所で構面外変形を拘束している. 図中の 矢印の位置で変位を計測し部材の変形角を求めた. 実験は載荷点の変 位で制御し, 振幅は試験体架構の全塑性耐力に対応する弾性変形角 $\theta_{y}$ $(=0.021 \mathrm{rad})$ を基準に, その整数倍で各振幅 2 サイクルずつ $4 \theta_{y}$ まで 漸増振幅で正負繰り返し載荷した.それでも試験体が破断しない場合 は振幅 $4 \theta_{y}$ による載荷を破断するまで繰り返した．また，加力は振幅 に応じて振動数の異なる正弦波を用い，最大層間変形角速度が $0.22 \mathrm{rad} / \mathrm{s}$ の動的載荷とした。

\section{3 実駼結果}

実験から得られた各試験体の履歴特性と最終破断状況の写真を図 12

表 6 試験体柱梁接合部の溶接外観検査結果

\begin{tabular}{|c|c|l|}
\hline 試験体 & \multicolumn{1}{|c|}{ 位置 } & \multicolumn{1}{|c|}{ 外観検査結果 } \\
\hline L1U & 梁フランジ溶接部 & $\begin{array}{l}\text { 上フランジ : 始終端部溶込み不良 } \\
\text { 下フランジ : 始終端部溶込み不良 }\end{array}$ \\
\hline L3U & 梁フランジ溶接部 & 欠陥なし \\
\hline L4U & 梁フランジ溶接部 & $\begin{array}{l}\text { 上フランジ : 余盛不足, 始終端部溶迟み不良 } \\
\text { 下フランジ : 始終端部溶込み不良 }\end{array}$ \\
\hline T1U & 柱仕口溶接部 & 補強隅肉, オーバーラッブ, ビード不整, 余盛不足 \\
\hline
\end{tabular}

〜 15 に示す，履歴特性は，縦軸に載荷荷重 $P$ を試験体が全塑性に至 る水平耐力 $P_{y}$ で無次元化した值, 横軸に部分架構の層間変形角 $\theta$ をと る.図中に終局に至った点を○、破断した点を×で示す、終局はその サイクルの最大荷重が, それ以前の最大值の $90 \%$ \%下回ったとき，ま たは破断が生じたときとした。.また事前のUT検查で溶接欠陥が検出 されたを試験体については久陥の位置を各図(c)に継目断面の黒丸と, 平面図の太線で示した，実験で観察された破壊状況を以下に記す。 (1) L 形試験体（L1U，L3U，L4U)

3 体之も層間変形角振幅 $0.06 \mathrm{rad}$ の 2 サイクル目で，層間変形角 0.05rad あたりから梁フランジの局部座屈が生じて耐力が低下し，最 大耐力の $90 \%$ 以下となって終局と判断された.この終局までの履歴挙 動は 3 体の試験体でほぼ同じであるが, その後の半サイクルから 1 サ イクルの間に,それぞれ梁フランジの溶接部周辺の異なる位置から亀 裂が生じて延性破断した。UT検査結果を参照しながら，久陥の有無 による破壊過程の違いを以下に説明する

L1U（図 12）：外観検查では上下フランジの溶接始終端部に溶込み不 良が観察されたが，UT検査による内部欠陥は検出されなかった。実 験では振幅0.06radの 2 サイクル目で下フランジ側のスカラップ底か らフランジ母材へ亀裂が進展して全面破断した．L形の3 体の中で唯 一，溶接部から破断しなかった試験体である。この破壊形式はスカ ラップの形状が原因で応力集中により生じることが既往の研究で指摘 されている，例えば山本ら17), 田渕ら18)の実験をまとめた文献 19)に よれば，スカラップ底にアールがない場合，裏当て金の組立溶接がス カラップ底に重なるときに特に変形能力が小さく,また裹はつり形式 でもかなり変形能力が小さいことが確認されている.この試験体は当 時の接合詳細の特徵である,底にアールのないスカラップ形状が原因 で変形能力の限界に至ったと考えられる。

L3U（図 13）: 外観検査で不良はなかったが，UT 検査では図 13(c)に 示す欠陥が検出され，特に初層の端部に多く集中していた。実験では 梁フランジ局部座屈で耐力が低下した後に, 梁フランジ溶接の始終端 からの亀裂が起点となり，ほぼダイアフラム側の熱影響部に沿って延 性破断した. スカラップ周辺にはL1Uに見られた損傷は観察されず， また上フランジ側は通しダイアフラムの出寸法が大きいこともあり特 に損傷は観察されたなかった．亀裂の発生位置はUT検査による欠陥 の位置と一致し, また載荷後の破面観察でこの亀裂の起点となった溶 接端部には幅 $5 \mathrm{~mm}$ 程度の赤錆が板厚方向に貫通する位置に観察され ていて,この未溶着部分が破断に至った原因と判断される. 後述の破 断までの変形能力はこの試験体が最も低く,溶接端部の板厚貫通欠陥

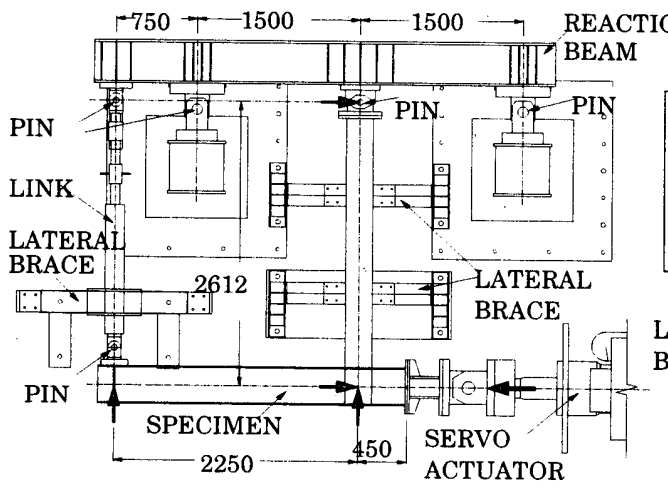

(a) L 形試験体

図 11 試験体と載荷装置・変位計測位置

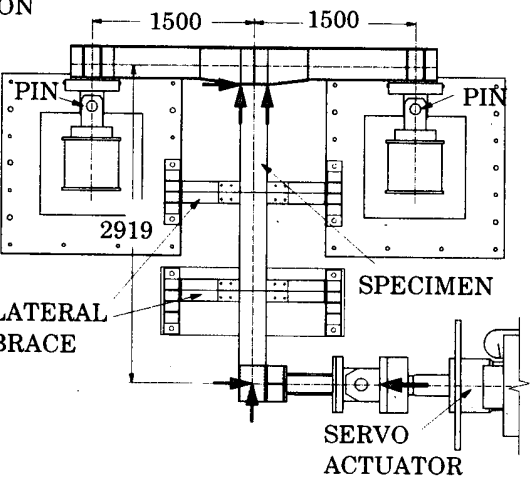

(b) $\mathrm{T}$ 形試験体

(単位 $: \mathrm{mm}$ )
表 7 試験体の全塑性耐力計算值

\begin{tabular}{|c|c|c|c|}
\hline \multirow{2}{*}{ 試験体 } & ${ }_{c} M_{p}$ & ${ }_{b} M_{p}$ & ${ }_{b} M_{p e}$ \\
\hline & \multicolumn{3}{|c|}{$\mathrm{kN} \cdot \mathrm{m}$} \\
\hline L1U & \multirow{2}{*}{264} & \multirow{2}{*}{277} & \multirow{2}{*}{252} \\
\hline $\mathrm{T} 1 \mathrm{U}$ & & & \\
\hline \multirow[t]{3}{*}{ L3U,L4U } & 267 & 275 & 250 \\
\hline & ${ }_{c} P_{y}$ & ${ }_{b} P_{y}$ & ${ }_{b} P_{y e}$ \\
\hline & \multicolumn{3}{|c|}{$\mathrm{kN}$} \\
\hline L1U & 108 & 112 & 102 \\
\hline $\mathrm{T} 1 \mathrm{U}$ & 96.2 & 207 & 188 \\
\hline L3U,L4U & 110 & 111 & 101 \\
\hline
\end{tabular}


は破断と変形能力の低下に大きく影響するという鈴木ら111の指摘に 符合する.

L4U（図 14）：外観検査で梁フランジ溶接に余盛不足や始終端部の溶 込み不良が確認された。 UT検査でも欠陥が見つかり，上フランジは ダイアフラム側に, 下フランジは開先側に位置していた. 実験では上 フランジの溶接始終端部の亀裂から破断し, 破断線の大部分はダイア フラムの母材であった. 亀裂の発生位置は, UT 検相により欠陥が検 出された位置とは一致しないが, 外観検查で溶接始終端部の溶接不良 や余盛不足が確認された位置であり、外観に現れたこれらの欠陥が破 断に影響しているとみられる.なお、下フランジのスカラップ底にも わずかに亀裂が発生したが、これが全面破断に至る前に、上フランジ

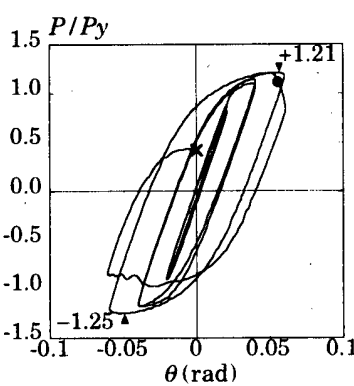

(a) 履歴曲線

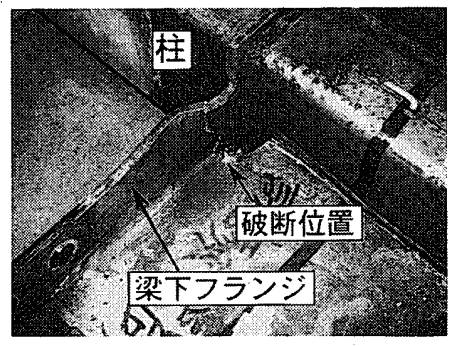

(b) 破断状況写真

図 12 L1U の実験結果

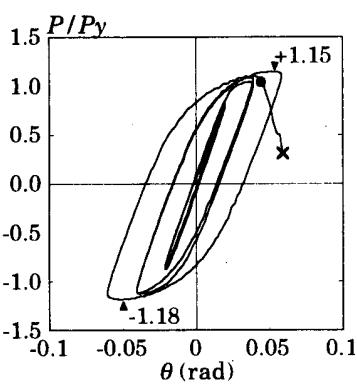

(a) 履歴曲線

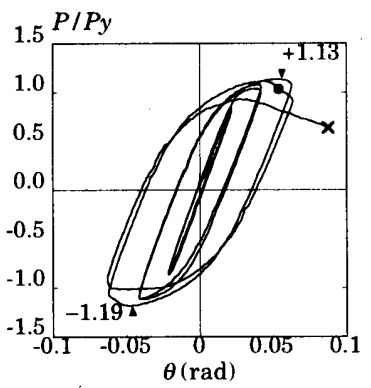

(a) 履歴曲線

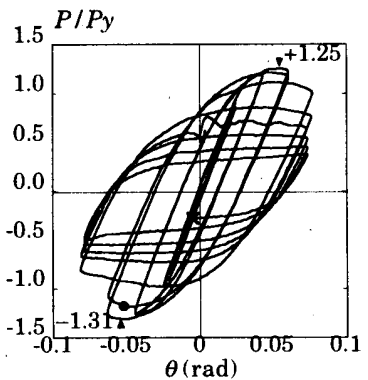

(a) 履歴曲線

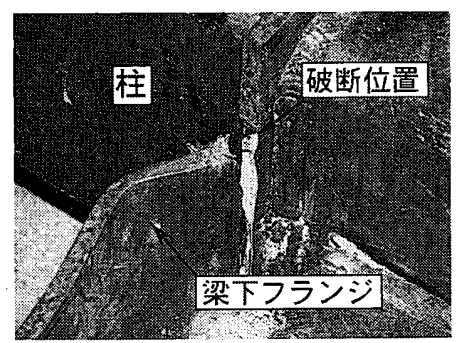

(b) 破断状況写真

の破断が先行した.

(2) $\mathrm{T}$ 形試験体 ( $\mathrm{T} 1 \mathrm{U}$, 図 15)

表 7 の部材耐力を見ると梁端が柱端の約 2 倍の耐力を持ち, 損傷は 柱端に生じることが予想される試験体である. 振幅 $0.06 \mathrm{rad}$ の載荷を 2 回繰り返した後に柱母材が局部座屈し，次の $0.08 \mathrm{rad}$ の振幅を 3 回 繰り返した後, 柱の局部座屈で大きな繰り返し面外変形を受けた部分 から亀裂が発生して柱が破断した. 梁端溶接部やスカラップ底には損 傷が観察されなかったＵT検査では図15(c)に示すように通しダイア フラムと柱の溶接の初層に全線にわたる大きな欠隡などが見つかった が、この溶接には図8(b)に例示する補強隅肉がされていて，これが内 部欠陷に起因する破断を防いだと考えられる。この補強隅肉は，他の 試験体でも柱とダイアフラムの溶接に多く用いられており，溶接継目 の耐力に対する補強効果があると見られる。

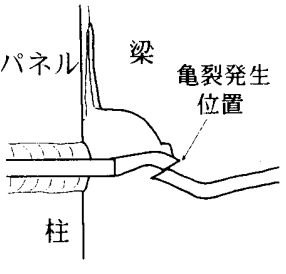

(c) 破断部スケッチ

\begin{tabular}{|c|c|c|c|}
\multicolumn{2}{c}{ 表 8 各試験体の変形能力 } \\
\hline \multirow{2}{*}{ 試験体 } & $\begin{array}{c}\text { 最大層間変形角 } \\
\mathrm{rad}\end{array}$ & \multicolumn{2}{|c|}{ 累積塑性変形倍率 $\eta$} \\
\cline { 3 - 4 } & 終局時 & 破断時 \\
\hline $\mathrm{L} 1 \mathrm{U}$ & 0.0610 & 13.9 & 18.0 \\
\hline $\mathrm{L} 3 \mathrm{U}$ & 0.0608 & 12.9 & 13.7 \\
\hline $\mathrm{L} 4 \mathrm{U}$ & 0.0635 & 13.9 & 21.6 \\
\hline $\mathrm{T} 1 \mathrm{U}$ & 0.0814 & 16.7 & 56.2 \\
\hline
\end{tabular}

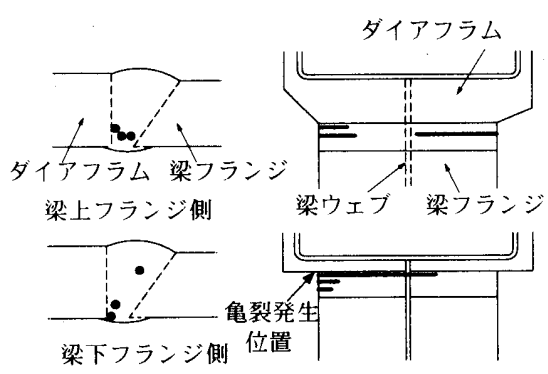

(c) UT 検査結果

(d) 破断部スケッ升

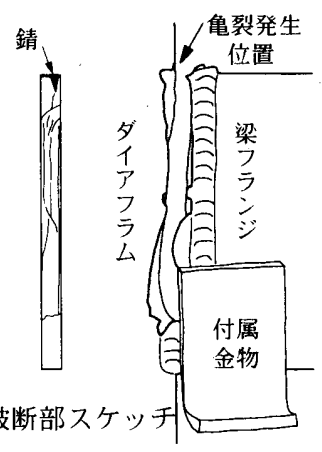

図 13 L3U の実験結果

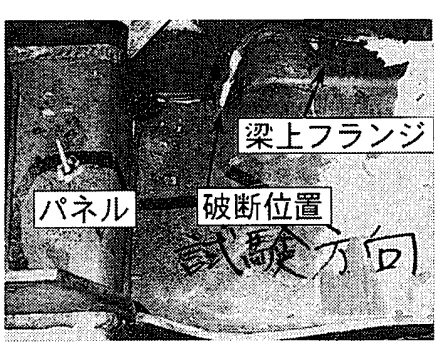

(b) 破断状況写真

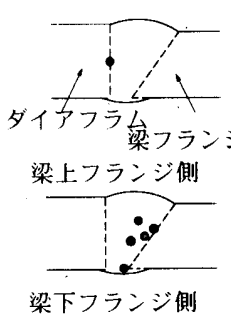

梁下フランジ側

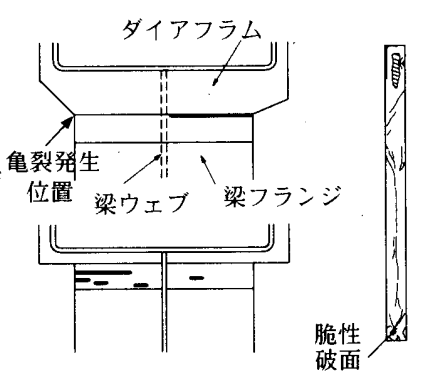

(d) 破断部スケ

(c) UT 検査結果

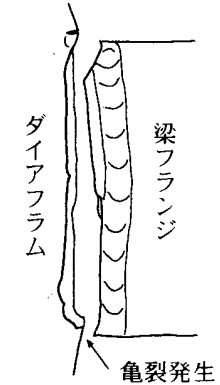

立置

図 14 L4U の実験結果

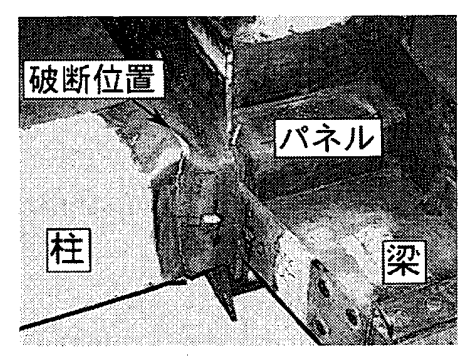

(b) 破断状況写真

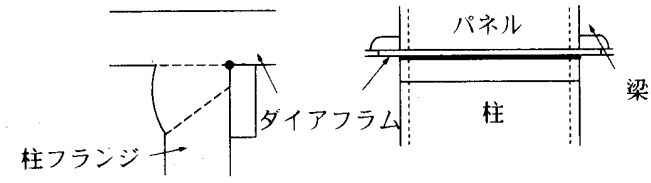

柱フランジ（Y1 側）
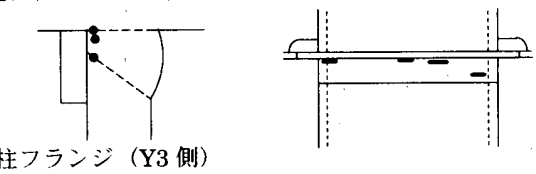

(c) UT 検査結果

図 15 T1U の実験結果 


\section{4 柱梁接合部の変形能力}

実験から得た変形能力を表 8 にまとめる. 最大変形角はどの試験体 も0.06radを超えてかなり大きいが, その理由には弾性限変形角 $\theta_{y}$ が 0.021 radと大きいことがある. 梁端接合部が破断したL形では最大塑 性変形角が $0.03 \mathrm{rad}$ 程度まで持ちこたえたが,これは板厚が $11 \mathrm{~mm}$ と 比較的小さく, 鋼材は $400 \mathrm{~N} / \mathrm{mm}^{2}$ 級で機械的性質が十分な強度と靭性 を持ち, 破面の大部分が延性破断であったことが関係すると考えられ る.だが, 実験から得た履歴曲線の囲む面積を $P_{y} \theta_{y}$ で除して計算され る累積塑性変形倍率 $\eta$ を見ると、フランジの局部座屈で決まる終局ま での值は L 形が 3 体とも $13 \sim 14$ でほぼ同じ值を示し、T形はこれよ りやや大きく 17 程度である. 破断までの值を比較すると, L 形は 3 体 の試験で 1.5 倍ほどの差があるが，これは溶接欠陥との関係で破断位 置や発生時期が異なったことによる.この $\eta$ の大きさを既往の研究と 比較すると, 弾性限変形の大きさや載荷履歴が異なるので直接の比較 は難しいが, それでも文献 20)などで示されている久陥のない現在の 接合詳細による場合の変形能力が概子 40 以上であるのと比較して小 さく, 文献 19)でスカラップ底にアールのない場合に多く示される 5 〜 10 に近い值であり，㑇による变形能力の低下が認められる，ま た， T形は終局から破断までの間で $\eta に$ 余裕があるが，これは局部座 屈の繰り返しで破断に至ったことによる。

\section{5 . 結論}

$1980 \sim 1981$ 年に建設された平屋建て鉄骨建物 2 棟を対象に柱梁接 合部の溶接品質をUT 検査, 外観検査とマクロ試験で調ベ，また柱梁 接合部の一部を切り出して動的載荷により変形能力を調べた。一例で はあるが，当時の鉄骨建物の品質と性能について以下の知見を得た. (1) 角形鋼管柱と H 形鋼梁を通しダイアフラム形式で接合する場合の 溶接詳細として, 開先加工, スカラップ加工, 溶接詳練などの現在の 標準と異なる詳細を確認した。

(2) 完全溶込み溶接のUT 検査では，建物により欠陥数や合格率の平 均が最大 4 倍ほど異なり, 裹はつり形式の梁フランジは合格率が高い が, 裏当て金形式の柱やパネルと通しダイアフラムの溶接に欠陌が多 く検出された. 特に, 初層のダイアフラム側, 初層のフランジ側に多 く, 両者で全体の $70 \%$ 近くを占めた. 欠陥の発生に対する技量と溶接 方法や管理技術の影響が改めて確認された。

(3) マクロ試験の結果から，溶接欠陥の種類によって発生する位置と 比率が異なる実態を示した. UT 検査による欠陥検出率を比較した結 果, スラグ巻込み, 融合不良, 割れの欠陥の $76 \%$ を検出することがで きた．また，鋼管柱の溶接部の検出率は表層よりも初層が 1.8 倍ほど 高いなど, 溶接部位と欠䧩位置により UT 検査による㭘出率に差がみ られた。

（4）柱梁接合部を繰返し載荷した実験から接合詳細や溶接欠陥と, 破 壊性状や変形能力の関係を調べた. 梁端溶接部が最危険断面の L 形試 験体では梁フランジの延性破断により破壊に至ったが, 溶接欠陥がな い場合は鋭角なスカラップ底からの亀裂が起点となり, また, 溶接欠 陥がある場合は欠陥の関与する位置からの亀裂が起点となり, 欠陥の 有無と位置により破壊過程と塑性変形能力が異なることを確認した． 破断までの累積塑性変形倍率は $14 \sim 22$ で, 現在の接合詳細による欠 皕のない接合部よりも小さく，また欠陥による低下が認められた，最 大塑性変形角は $0.03 \mathrm{rad}$ 程度であった

\section{謝辞}

既存建物の鉄骨をご提供いただいた関係の方々、並びに溶接部の検 查にご協力いただいた故 浅野孝男氏（ダブルアイエル），丸岡義臣氏 (丸岡義臣技術研究所)に厚く感謝の意を表します. 本研究の一部は科 学研究費・基盤研究 B（代表者：吹田啓一郎）の助成を受けた.

\section{参考文献}

1）加藤勉，古沢平夫，森田耕次：超音波斜角探傷法による欠陥の評価(1)，日 本建築学会論文報告集、第 241 号, pp.33-41，1976 年 3 月

2) 加藤勉, 古沢平夫, 森田耕次: 超音波斜角探傷法による欠陷の評価(II)，日 本建築学会論文報告集、第 244 号、pp.21-31，1976 年 6 月

3）加蕂勉，森田耕次，古沢平夫，下村波基 : 欠陥を有する溶接部の耐力之変形 能力に関する研究、日本建築学会構造系論文報告集、第 350 号, pp.86-93, 1985 年 4 月

4) 藤本盛久, 泉満: 欠陥を有する溶接部の变形能力に関する研究 ( T 継手突合 せ溶接部の低サイクル塑性疲労実験 その1）、日本建築学会論文報告集， 第 288 号, pp.61-71, 1980 年 2 月

5) 藤本盛久，泉満：欠陥を有する溶接部の変形能力に関する研究 (T継手突合 せ溶接部の低サイクル塑性疲労実験 その 2), 日本建築学会論文報告集, 第 303 号, pp.21-30, 1981 年 5 月

6) 佐藤邦彦, 豊田政男, 岡本修平: 骨組構造物に拝引る溶接欠陥を持つ部材の 全面降伏後破罗性能に関する研究（第 1 報），溶接学会誌、第 50 巻第 1 号 pp.71-77, 1981 年 1 月

7) 佐藤邦彦. 豊田政男, 岡本修平: 骨組構造物に㧈ける溶接欠陥を持つ部材の 全面降伏後破壊性能に関する研究（第 2 報）、溶接学会誌，第 50 巻第 7 号， pp.42-48, 1981 年 7 月

8）小野徹郎, 中川進一郎: $\mathrm{COD}$ 破壊基準による切欠付平板引張実験の検討 (欠 陥を有する溶接接合部の破罗挙動に関する研究その1), 日本建築学会構造 系論文報告集，第 347 号, pp.75-82、1985 年 1 月

9) 小野徹郎, 中川進一郎, 鈴木孝彦: 切欠付平板の破壊挙動に関する数值解析 (欠陥を有する溶接接合部の破壊挙動に関する研究その 2 ), 日本建築学会 構造系論文報告集，第 352 号, pp.90-97，1985 年 6 月

10）小野徹郎. 中川進一郎: 欠陥を有する柱一はり接合部の塑性変形能力に関す る破壊力学的検討 (欠陥を有する溶接接合部の破壊挙動に関する研究その 3), 日本建築学会構造系論文報告集, 第 357 号. pp.72-80，1985 年 11 月

11）鈴木孝彦・石井匠・森田耕次・高梨晃一: 宿を有する柱梁接合部の破断性 状に関する実験的研究，日本鋼構造協会、鋼構造論文集、第 6 巻第 23 号, pp.149-164, 1999 年 9 月

12）嶋徽，石原完爾，濱田弘行，原田幸博，西川耕二，鄭聖王民，鉿木畺一、森 田耕次:始終端部に欠欠陥を有する乫合せ溶接部の脆性的破壊に関する実験的 研究, 日本鋼構造協会, 鋼構造論文集, 第 10 巻第 38 号, pp.17-30, 2003 年 6 月

13）田㴊基嗣，田中剖、吉村鉄也，安井一浩、石原完爾、横田和伸，藤田哲也 三村麻里：梁端部の溶接欠陥が梁の塑性変形能力に及ぼす影響（その 5 〜 9 ，日本建築学会大会学術講演梗概集 (東海), C-1 構造 II , pp.867-876 2003 年 9 月

14）尾熊政男, 石原節夫, 大垣克己, 高松隆夫, 松尾彰、南宏一，山口清司、丸 山陵 : 既存鉄骨造屋内運動場の耐震性能に関する研究（その $5 \sim$ その 10), 日本建築学会大会学術講演梗概集 (東海)，C-1構造 III, pp.1023-1034，2003 年 9 月.

15）銅構造建築溶接部の超音波探偒検查規淮・同解説、日本建築学会，1989 年

16）佐藤有希，吹田啓一郎：既存鉄骨建物の柱梁接合部の耐震補強, 日本鋼構造 協会，鋼構造年次論文報告集，第 11 巻，pp.451-458，2003 年 11 月

17) 山本昇, 石井匠, 森田耕次: はり端溶接接合部の力学的挙動におよぼすス力 ラップ形状の影響、構造工学論文集, Vol.39B, pp.493-506, 1993 年 3 月.

18）田㴊基嗣，金谷弘，佐柳光昭 : 鋼管柱・はり接合部の力学性状に与える接合 部詳細の影響（その7内ダイアフラム補剛形式接合部の実験結果）、日本建 築学会大会学術講演梗概集 (東北)，C構造 II，pp.1139-1140，1991年.9月.

19）鋼構造接合部の力学性状に関する研究の現状, 4.2節 スカラップ. 日本建築 学会 (鋼構造運営委員会・接合小委員会)，pp.135-142，1993 年 10 月.

20）井上一朗, 甲津功夫, 吹田啓一郎, 多田元英, 立山英二, 田中剛, 中島正愛, 丸岡義臣, 南二三吉, 森田耕次: 通しダイアフラム形式で角形鋼管柱に接合 されるH形鋼梁の塑性变形能力に関する実大実験（その $1 \sim 5)$, 日本鋼構 造協会，銅構造論文集，第 4 巻第 16 号, pp.27-104, 1997 年 12 月

21) 吹田啓一郎, 佳藤有希, 長田暢浩: 既存鉄骨建物の耐震性能之耐震補強 (そ の1 3), 日本建築学会大会学術講演梗概集 (東海). C-1 構造 III, pp.937942,2003 年 9 月 